\title{
Ege Bölgesi Sahil Kuşağına Uyumlu Arpa (Hordeum vulgare L.) Çeşit ve Genotiplerinin Verim ve Bazı Kalite Özelliklerinin Belirlenmesi
}

\author{
*Aydın İMAMOĞLU1 Seda PELIT' ${ }^{1}$ Nurgül SARI ${ }^{2}$ \\ Ceylan BÜYÜKKILECi ${ }^{1}$ Özge YILDIZ ${ }^{1}$ \\ ${ }^{1}$ Ege Tarımsal Araştırma Enstitüsü, İzmir \\ ${ }^{2}$ Tarla Bitkileri Merkez Araştırma Enstitüsü, Ankara \\ *Sorumlu yazar e-posta (Corresponding author; e-mail): aydinimamoglu@hotmail.com
}

\section{Öz}

Bu Çalışma, Ege Bölgesi Sahil Kuşağına uygun ümitvar arpa hatlarının 2013-2014 üretim sezonunda verim ve kalite özelliklerini belirlemek amacıyla, Ege Tarımsal Araşııma Enstitüsü deneme tarlaları ile Karacabey Tarım Işletmesi tarlalarında kurulmuştur. Arazi denemeleri tesadüf blokları deneme deseninde, dört tekerrürlü tek deneme şeklinde yürütülmüştür. Denemede Ege Bölgesi Arpa Islah Araştırmaları projesinde ön plana çıkmış 20 adet arpa hattı ile beraber beş adet (Kaya7794, Akhisar 98, Hilal, Sancak ve Bayrak) tescilli çeşit standart olarak yer almıştır. Bu hat ve çeşitlere ait tane verimi (kg/da), bin tane ağırlığı $(\mathrm{g})$, hektolitre ağırlığı $(\mathrm{kg} / \mathrm{hl})$, tane irilik oranı (\%) ve protein oranı (\%) özellikleri belirlenmiştir. Yürütülen çalışmada lokasyonların standartların ortalaması $359 \mathrm{~kg} / \mathrm{da}$ olup deneme ortalamaları $395 \mathrm{~kg} / \mathrm{da}$ olarak gerçekleşmiştir. Lokasyonlarda en yüksek standart 409 $\mathrm{kg} / \mathrm{da}$ ile Sancak olurken, en düşük standart $290 \mathrm{~kg} / \mathrm{da}$ ile Kaya7794 olmuştur. Lokasyonların ortalamasını 8 hat geçerken 506 numaralı hat $552 \mathrm{~kg} / \mathrm{da}$ ile en yüksek verimi verirken $548 \mathrm{~kg} / \mathrm{da}$ ile $523,522 \mathrm{~kg} / \mathrm{da}$ ile de 509 numaralı hat 2 inci ve 3 üncü sıraları almışıı. Verim bakımından Menemen lokasyonu ilk sırada yer almıştır. Yapılan elek analizinde $2.5+2.8 \mathrm{~mm}$ ve üzerinde $\% 95$ irilik değeri ile 512 numaralı hat ilk sırada yer alırken bunu $\% 92$ irilik değeri ile 511 numaralı hat takip etmiş standartlardan Hilal çeşidi \%91 irilik değeri ile üçüncü sırada yer almıştır. Tane iriliği bakımından Karacabey lokasyonu ilk sırayı almıştır. Protein yüzdeleri bakımından Karacabey lokasyonu ilk sırayı almış, hektolitre ve 1000 tane ağılıkları bakımında lokasyonlar birbirlerine yakın değerler vermişlerdir. Çalışma sonunda en yüksek tane verimi 506,523 ve 509 numaralı hatlardan, en yüksek bin tane ağılı̆̆ı 508, 511 ve 521 numaralı hatlardan elde edilirken, 506, 515 numaralı hatlar ve Sancak en yüksek hektolitre ağırlığı değerlerine ulaşmıştır. En yüksek protein \% si ise 515, 509, 507 ve 517 numaralı hatlardan elde edilmiştir. Sonuçlara göre, Ege Bölgesi sahil kuşağına uyumlu ümitvar arpa hatlarında; tane verimi ve bazı kalite kriterlerine göre 506, 523, 509, 522, 519, 512 ve 519 numaralı hatlar ümitvar olarak bulunmuştur

Anahtar Kelimeler: Arpa , Hordeum vulgare L., verim, kalite, hat

\section{Determination of Improved Barley Lines and Varieties Suitable for the Coastal Areas Conditions of Aegean Region}

\begin{abstract}
This study was conducted to in 2013-14 growing seasons find out improved barley lines suitable for Aegean Agricultural Research Instutue and Karacabey agricultural enterprises field. Experimental design was completely randomized blocks desingns with four replications for the field trials. Following characters were assessed for 20 lines and five registered varieties (Akhisar98, Vamıkhoca98, Kaya7794, Bornova92, Hilal): grain yield (kg/da), 1000 grain weight $(\mathrm{g})$, hektoliter weight $(\mathrm{kg} / \mathrm{hl})$ and big grain rate $(\geq 2.5 \mathrm{~mm})$, and protein days to spikeling. In the end of the study, the high yield improved barley lines were lines 506.523 and 519, 1000 grain weights were higher for the lines 508.511 and 521 whereas lines 506.515 and Sancak had higher hektoliter. Protein rates were higher for the lines 515.505, 507 and 517 weight. According to results, the improved barley lines 506, 523, 509, 522, 519, 512 and 519 were found out promising lines for The Coastal Areas of Aegean Regıon for high yield, and some more guality properties.
\end{abstract}

Keywords: Barley, Hordeum vulgare L., grain yield, guality, line

\section{Giriş}

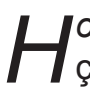
ordeum vulgare L., buğday, mısır ve çeltikten sonra önemli tahıl cinsidir. Arpa, başta hayvan beslenmesi olmak üzere, malt ve bira endüstrisinde, az da olsa insan beslenmesinde kullanılmaktadır (Poehlman, 1985). Dünyanın bazı bölgelerinde ise insan gıdası olarak kullanılmaktadır (Yürür 1998). 
Serin iklim tahılları içerisinde arpa, dünyada ve Türkiye'de de ekiliş ve üretim yönünden buğdaydan sonra 2. sırayı alan tahıldır (Kün, 1988).

Arpa, Türkiye'de 3 milyon hektar ekim alanı ve 7.3 milyon ton üretimi ile tahıllar içerisinde buğdaydan sonra ikinci sırada yer almaktadır. Türkiye'nin de önemli gen merkezlerinden biri olduğu ve tane ürününün \%90'ı ve sapının büyük bir kısmı hayvan beslenmesinde, geri kalan kısmı ise malt endüstrisinde kullanılan arpa $243 \mathrm{~kg} / \mathrm{da}$ ortalama verimi ile ülkemiz tarımında önemli bir yere sahiptir. Bölgemizde de ekiliş alanı bakımından arpa, buğdaydan sonra ikinci sırada yer alırken bunu pamuk ve mısır takip etmektedir (Anonim 2010).

Bulgurlu (1971), ülkemizde arpanın biracilıkta ve insan beslenmesinde kullanıldığını, hayvan beslemede ise en çok kuvvet yemi olarak tüketildiğini belirtmiştir. Araştırıcı kavuzsuz arpaların besleme değerinin, dış kabukları ince ve zayıf arpaların yanı sıra kavuzları kalın ve sert olan arpalara göre daha yüksek olduğunu belirtmiştir. Bununla birlikte dış kavuzları ince ve narin arpaların, kavuzları kalın ve sert olanlardan biraz daha yüksek besleme değerine sahip olduklarını da ifade etmiştir. Yemlik kalitesi iyi olan arpanın açık sarı renkli ve kendine has kokusu olduğunu belirtmiştir. Ayrıca, bin tane ağırlığının 35-50 gr. arasında, hektolitre ağırlığının ise $62-70 \mathrm{~kg}$ arasında olması gerektiğini vurgulamıştır. Kavuz miktarının \%717 arasında değiştiğini, bu miktarın ortalama olarak \%12 olması gerektiğini belirterek, kavuz miktarı artıkça arpanın yemlik değerinin düşeceğini belirtmiştir.

Kırtok ve Genç (1980), Yemlik arpa tanesinde bulunan $\% 7.5-15$ protein, $\% 72$ gerçek nişasta değeri, \%75 hazmolabilir besin maddeleri toplamı ile arpanın mısır yeminin \%95'ine eşdeğer olup, hayvanlar için iyi bir yem kaynağı olduğunu belirtmişlerdir.

Atlı ve ark. (1989), 5 arpa çeşidini kullanarak hektolitre ve bin tane ağırlığı, protein miktarı, elek analizi bulguları, kavuz ve ekstrakt miktarının stabilite ve kalıtım derecelerini hesaplamışlardır. En yüksek kalıtım değerini veren kriterlerin bin tane ağırlığı (0.707) ve $(2.5 \mathrm{~mm})$ elek üzeri (0.591) olduğunu belirterek, en düşük kalıtım derecesini ise protein miktarında (-0.009) elde ettiklerini bildirmişlerdir. Bunu sırasıyla ekstrakt miktarı (0.589), hektolitre ağırlığı (0.564) ve kavuz miktarının (0.538) izlediğini saptamışlardır. Tanedeki protein miktarı ile hektolitre ağırlığı ve $2.5 \mathrm{~mm}$ elek üzeri değerleri arasında pozitif ve önemli düzeyde ilişki olduğunu bildirmişlerdir.

Genellikle 1000 tane ağırlığı olarak ifade edilen tohum iriliği arpa tanesinde nişasta miktarının bir göstergesidir ve 1000 tane ağırlığı arttıkça nişasta oranı da artmaktadır. Ayrıca, tohum iriliği ve malt ekstrakt yüzdesi arasında olumlu ve önemli bir ilişki de bulunmaktadır (Engin, 1989). Maltık arpada 1000 tane ağırlığı 40 gramın üzerinde olmalıdır (Atlı ve ark. 1989).

Arpanın nişastaca zengin olması, maltın ekstrakt verimini artırır. Danedeki kuru maddenin büyük kısmını nişasta oluşturduğundan nişasta içeriğinin yüksekliği, ekstrakt içeriğinin de yüksekliğini gösterir. Arpada nişasta ile protein arasında negatif bir ilişki vardır. Protein içeriğinin yüksek olması, nişasta içeriğini dolayısıyla ekstrakt ve bira verimini düşürdüğü bildirilmektedir (Engin, 1989).

Elgün ve ark. (2001) tahıllarda protein miktarı çeşit, çevre ve toprak faktörlerine göre değişir. Protein miktarına iklim ve topraktaki alınabilir azot oranının önemli etkisi vardır. Topraktaki alınabilir azot oranı arttıkça tanedeki protein miktarı da yükselir. Engin ve ark. (1999), malt proteininin (\%) malt kalitesine etki eden en önemli kriterlerden biri olduğunu bildirmişler ve bu değerin \%9.0 ile 11.5 arasında olmasını önermişlerdir.

Arpa tanesinin bileşenleri arasında yoğunluğu en fazla olan nişastadır. Bu nedenle, hektolitre ağırlığı arpa tanesinin daha fazla nişasta ve malt ekstrakt oranına sahip olduğu anlamına gelmektedir (Engin, 1989). Maltlık arpalarda hektolitre ağırlığının 66 $\mathrm{kg} / \mathrm{hl}$ 'nin üzerinde olması istenir (Atlı ve ark. 1989).

$\mathrm{Bu}$ araştırmanın amacı, Ege Bölgesi koşullarında, ileri kademedeki arpa hatlarının verim ve bazı kalite kriterlerini belirlemek, yöreye uygun arpa genotiplerini saptamak ve bunları çeşit olarak geliştirmektir.

\section{Materyal ve Yöntem}

Araştırmanın materyalini Ege Tarımsal Araştırma Enstitüsü Arpa Islah Birimi materyali oluşturmaktadır. Araştırmada standart olarak Ege Tarımsal Araştırma Enstitüsüne ait Kaya, 
Hilal, Akhisar98, Sancak ve Bayrak çeşitleri kullanılmıştır. Çalışma 2013-2014 üretim yılında Ege Tarımsal Araştırma Enstitüsü deneme tarlaları, ile Karacabey Tarım İşletmesi tarlalarında tesadüf blokları deneme deseninde, dört tekerrürlü 25 hat ve çeşitten oluşan tek deneme şeklinde yürütülmüştür.

İleri kademede yer alan arpa hatları, standart çeşitler ile birlikte parselde $15 \mathrm{~cm}$ sıra arası ve $5 \mathrm{~m}$ sıra uzunluğu olmak üzere, 8 sıra ekilmiş ve parsel alanı $6 \mathrm{~m}^{2}$ olmuştur. Denemelerin ekimi hava koşullarına bağlı olarak 03.01.2014 tarihinde gerçekleşmiş, hasat 26.06.2014 tarihinde tanedeki su oranının \%13'ün altına düştüğü ve başakların tam olgunlaştığı dönemde parsel biçer döveri ile yapılmıştır.

\section{Bulgular ve Tartışma}

Ege Bölgesi Sahil Kuşağı koşullarında, 2013-2014 üretim yıllında denemelerden alınan arpa çeşit ve hatlarına ait tane verimi, bin tane ağırlığı, hektolitre ağırığı, tane irilik oranı, ve protein oranlarına ilişkin ortalama değerler Çizelge 1'de verilmiştir.

\section{Tane Verimi}

Hatlar tane verimleri açısından birbirinden önemli derecede farklı bulunmuştur. Denemelerde yer alan standartların ortalaması $359 \mathrm{~kg} /$ da olup deneme ortalamaları $395 \mathrm{~kg} / \mathrm{da}$ olarak gerçekleşmiştir. Lokasyonlarda en yüksek standart 409 kg/da ile Sancak olurken, en düşük standart 290 kg/da ile Kaya 7794 olmuştur. Lokasyonların ortalamasını 8 hat geçerken 506 numaralı hat 552 kg/da ile en yüksek verimi verirken bunu 523 ve 509 numara hatlar takip etmiş ve ilk verim grubunda yer almışlardır. Verim bakımından Menemen lokasyonu ilk sırada yer almıştır (Çizelge 1).

\section{Hektolitre Ağırlığı}

Hatlar hektolitre ağırlığı açısından birbirinden önemli derecede farklı bulunmuştur. Hektolitre ağırlıkları bakımında lokasyonlar

Table 1. Arpa bölge verim denemesi 1 verim ve gözlem sonuçları birleşik (2013-2014)

Table 1. Barley regional yield experiment no:1 yield and survey results (combined) (2013-2014)

\begin{tabular}{|c|c|c|c|c|c|c|c|c|c|}
\hline \multirow{2}{*}{$\begin{array}{l}\text { Ekim Tarihi } \\
\text { Hasat tarihi } \\
\text { Çeşit/Hat } \\
\text { No }\end{array}$} & \multicolumn{3}{|c|}{$\begin{array}{l}03 / 01 / 2014-14 / 12 / 2013 \\
26 / 06 / 2014-02 / 07 / 2014\end{array}$} & \multicolumn{2}{|c|}{$\begin{array}{l}\text { Parsel Ölçüleri } \\
\text { Tekerrür Sayısı }\end{array}$} & : & \multicolumn{3}{|c|}{$\begin{array}{c}5 \mathrm{~m} \times 0.15 \mathrm{~m} \times 8 \text { sıra : } 6 \mathrm{~m}^{2} \\
4 \text { (Tesadüf Blokları Deneme } \\
\text { Deseni) }\end{array}$} \\
\hline & $\begin{array}{l}\text { Verim } \\
\text { (kg/da) }\end{array}$ & Grup. & $\begin{array}{l}\text { Hektolitre } \\
\text { Ağırlığı } \\
\text { (kg) }\end{array}$ & Grup. & $\begin{array}{c}1000 \\
\text { Tane } \\
\text { Ağırlığı } \\
\text { (g) }\end{array}$ & Grup. & $\begin{array}{l}\text { Protein } \\
\text { Oranı } \\
(\%)\end{array}$ & $\begin{array}{c}\text { Elek } \\
\text { Tar.\% } \\
2.5+ \\
(\mathrm{mm})\end{array}$ & Grup. \\
\hline Kaya st. & 290 & $\mathrm{~K}$ & 62.0 & $A D$ & 38.8 & $\mathrm{HJ}$ & 13.0 & 73 & JK \\
\hline Hilal st. & 353 & FJ & 62.1 & $A C$ & 49.7 & $A$ & 13.3 & 91 & $A C$ \\
\hline Akhisar 98 st. & 360 & EJ & 55.1 & M & 43.1 & EF & 12.8 & 78 & FK \\
\hline Sancak st. & 409 & BE & 62.4 & $\mathrm{AC}$ & 37.5 & IJ & 12.5 & 72 & $\mathrm{~K}$ \\
\hline Bayrak st. & 384 & $\mathrm{DH}$ & 61.1 & BG & 36.6 & JK & 13.2 & 83 & $\mathrm{CH}$ \\
\hline 506 & 552 & $A$ & 63.9 & $A$ & 41.8 & $E G$ & 12.7 & 87 & $\mathrm{AE}$ \\
\hline 507 & 360 & EJ & 59.3 & FJ & 41.1 & $\mathrm{FH}$ & 13.6 & 83 & CG \\
\hline 508 & 373 & El & 61.5 & BF & 50.8 & $A$ & 12.7 & 85 & $\mathrm{BF}$ \\
\hline 509 & 522 & $A$ & 61.3 & BF & 42.1 & $\mathrm{EF}$ & 13.7 & 88 & $A D$ \\
\hline 510 & 402 & BF & 58.1 & HK & 41.1 & $\mathrm{FH}$ & 11.6 & 75 & HK \\
\hline 511 & 350 & GJ & 59.1 & GJ & 49.8 & $A$ & 12.8 & 92 & $A B$ \\
\hline 512 & 432 & BD & 61.7 & $A E$ & 49.1 & $A B$ & 12.9 & 95 & $A B$ \\
\hline 513 & 376 & $\mathrm{EH}$ & 56.8 & $\mathrm{KM}$ & 38.1 & IJ & 12.9 & 81 & DJ \\
\hline 514 & 382 & $\mathrm{DH}$ & 59.9 & DI & 34.4 & $\mathrm{~K}$ & 13.0 & 59 & $\mathrm{~L}$ \\
\hline 515 & 313 & JK & 63.2 & $A B$ & 47.0 & $B C$ & 14.1 & 85 & BF \\
\hline 516 & 370 & El & 55.3 & M & 43.6 & DE & 13.2 & 80 & EJ \\
\hline 517 & 356 & FJ & 59.4 & FJ & 43.1 & EF & 13.3 & 80 & EJ \\
\hline 518 & 344 & $\mathrm{HJ}$ & 60.3 & $\mathrm{CH}$ & 39.0 & $\mathrm{HJ}$ & 11.8 & 82 & DI \\
\hline 519 & 450 & $B C$ & 57.5 & JL & 45.8 & CD & 12.1 & 83 & CG \\
\hline 520 & 400 & CG & 58.0 & IL & 39.5 & GI & 12.6 & 75 & IK \\
\hline 521 & 368 & El & 55.8 & LM & 43.4 & DF & 13.2 & 81 & DJ \\
\hline 522 & 452 & $B$ & 61.2 & $B G$ & 44.0 & DE & 11.8 & 82 & DI \\
\hline 523 & 548 & A & 59.6 & EJ & 44.1 & DE & 11.8 & 83 & CG \\
\hline 524 & 394 & $\mathrm{DH}$ & 60.7 & CG & 43.0 & $\mathrm{EF}$ & 13.2 & 85 & $\mathrm{BF}$ \\
\hline 525 & 322 & IK & 61.3 & BF & 37.2 & IJ & 12.0 & 77 & GK \\
\hline $\mathrm{F}$ & ** & & $* *$ & & ** & & & & \\
\hline $\mathrm{DK}(\%)$ & 13.1 & & 3.778 & & 5.79 & & & 6.90 & \\
\hline AÖF (\%5) & 51.2 & & 2.23 & & 2.43 & & & 7.97 & \\
\hline Deneme Ort. & 395 & & 60 & & 43 & & & 81 & \\
\hline
\end{tabular}


birbirlerine yakın değerler vermişlerdir. Denemelerde en yüksek hektolitre ağırlığı 63.9 $\mathrm{kg} / \mathrm{hl}$ ile 506, $63.2 \mathrm{~kg} / \mathrm{hl}$ ile 515 numaralı hatlardan alınırken bunu $62.4 \mathrm{~kg} / \mathrm{hl}$ ile Sancak çeşidinden elde edilmiştir. 512, 508, 509, 525 ve 522 numaralı hatlar $60 \mathrm{~kg} / \mathrm{hl}$ olan deneme ortalamasının üstünde değer almışlardır (Çizelge 1).

\section{Bin Tane Ağırlığı}

Hatlar bin tane ağırlığı açısından önemli derecede farklı bulunmuştur. Ortalama bin tane ağırlığı $43.07 \mathrm{~g}$ olurken, en yüksek bin tane ağırlığı $50.8 \mathrm{~g}$ ile 508 numaralı hattan, en düşük bin tane ağırlığı ise $34.4 \mathrm{~g}$ ile 514 numaralı hattan elde edilmiştir. Bin tane ağırlığı bakımından 508, 511, 512, 515, 519, 522, 516 ve 521 numaralı hatlar deneme ortalamasının üzerinde yer almıştır (Çizelge 1).

\section{Protein Oranı (\%)}

Protein yüzdeleri bakımından Karacabey lokasyonu ilk sırada yer alırken bunu Menemen lokasyonu izlemiştir. Denemede yer alan hat ve çeşitlere ait değerler \%11.6-14.1 arasında değişmektedir.

En yüksek protein \%14.1 ile 515 numaralı hattan elde edilirken, bunu 509 ve 507 numaralı hatlar takip etmiştir. En düşük protein oranı ise \%11.6 ile 510 numaralı hattan elde edilmiştir.

\section{Tane İriliği}

Yapılan elek analizinde $2.5+2.8 \mathrm{~mm}$ ve üzerinde \%95 değer ile 512 numaralı hat ilk sırayı alırken bunu \%92 ile 511numaralı hat takip etmiştir. \%93.8 irilik değeri ile standartlardan Hilal çeşidi üçüncü sırada yer almıştır. Tane iriliği bakımından Karacabey lokasyonu ilk sırayı alırken bunu Menemen lokasyonu izlemiştir (Çizelge 1).

\section{Sonuç}

Ege Bölgesi Sahil kuşağı koşullarına uygun ümitvar arpa hat ve çeşitlerinin verim ve bazı kalite özelliklerini incelediğimiz bir yıllık bir araştırmadan elde edilen sonuçlara baktığımızda verim açısından denemede en yüksek tane verimini 552 kg/da ile 506, 548 $\mathrm{kg} / \mathrm{da}$ ile $523,522 \mathrm{~kg} / \mathrm{da}$ ile 509 nolu hatlardan elde edilirken, standart çeşitlerden kontrol Sancak 409 kg/da ile 7 inci sırada yer almıştır. En düşük tane verimi ise $290 \mathrm{~kg} / \mathrm{da}$ ile standart Kaya 7794 kontrol çeşidinden elde edilmiştir. Denemede yer alan 506, 509 ve 523 numaralı hatlar 1 'inci verim gurubunda yer almışlar, verim bakımından Menemen lokasyonu ilk sırada yer alırken bunu Karacabey lokasyonu izlemiştir. 1000 tane ağırlığı bakımından 508 ve 511 numaralı hatlar ilk iki sırayı alırken standart Hilal çeşidi üçüncü sırayı almıştır.

Protein yüzdeleri bakımından Karacabey lokasyonu ilk sırada yer alırken bunu Menemen lokasyonu izlemiştir. Denemede yer alan hat ve çeşitlere ait değerler \%11.6 - 14.1 arasında değişmektedir. En yüksek protein \%14.1 ile 515 numaralı hattan elde edilirken, bunu 509 ve 507 numaralı hatlar takip etmiştir. En düşük protein oranı ise \%11.6 ile 510 numaralı hattan elde edilmiştir.

Hektolitre ağırııları bakımında lokasyonlar birbirlerine yakın değerler vermişlerdir. Denemelerde en yüksek hektolitre ağırlığı 63.9 $\mathrm{kg} / \mathrm{hl}$ ile 506, $63.2 \mathrm{~kg} / \mathrm{hl}$ ile 515 numaralı hatlardan alınırken bunu $62.4 \mathrm{~kg} / \mathrm{hl}$ ile Sancak çeşidinden elde edilmiştir. 512, 508, 509, 525 ve 522 numaralı hatlar $60 \mathrm{~kg} / \mathrm{hl}$ olan deneme ortalamasının üstünde değer almışlardır (Çizelge 1).

Yapılan elek analizinde $2.5+2.8 \mathrm{~mm}$ ve üzerinde \%95 değer ile 512 numaralı hat ilk sırayı alırken bunu \%92 ile 511numaralı hat takip etmiştir. \%93.8 irilik değeri ile standartlardan Hilal çeşidi üçüncü sırada yer almıştır. Tane iriliği bakımından Karacabey lokasyonu ilk sırayı alırken bunu Menemen lokasyonu izlemiştir. (Çizelge 1).

Bölge verim denemelerinde 2 yıl sonuçları bu yayında verilmiş olup, yapılan tüm değerlendirmelerden sonra denemelerde yer alan 506 numaralı hat TROYA, 523 numaralı hat BÜRKÜT isimleri ile tescile aday gösterilerek üretim izinleri alınmış ve tohumluk üretim programına dahil edilerek Türk çiftçisinin beğenisine sunulmuştur.

\section{Kaynaklar}

Anonim, 2007. T.C. Başbakanlık Türkiye İstatistik Kurumu, Ankara. http://www.tuik.gov.tr

Anonim, 2010. T.C. Başbakanlık Türkiye İstatistik Kurumu, Ankara. http://www.tuik.gov.tr

Atlı A., Koçak N., Köksel H. ve Tuncer T., 1989. Yemlik ve maltlık arpada kalite kriterleri ve arpa ıslah progamlarında kalite değerlendirmesi. Arpa Malt Semineri, Konya, s. 23-37

Bulgurlu Ş., 1971. Yemler. Ege Üni. Zir. Fak. Yayın No. 100. Ders Kitabı, Bornova, İzmir. 
Imamoğlu et al. "Determination of Improved Barley Lines and Varieties Suitable for The Coastal Areas Conditions of Aegean Region"

Elgün A., Türker S. ve Bilgiçli N., 2001. Tahıl ve ürünlerinde analitik kalite kontrolü. Selçuk Üniv. Ziraat Fak. Gıda Müh. Bölümü. Yay. No: 2, Konya

Engin A.,1989. Biralık arpalarda önemli kalite özellikleri ve bunların malt kalitesi üzerine etkileri. Arpa-Malt Semineri, S:38-41, Konya

Engin A., Başgül A. ve Özkara R., 1999. Orta Anadolu'da Hububat Tarımının Sorunları ve Çözüm Yolları Sempozyumu, 8-11 Haziran 1999, Konya, 524-531

Çölkesen M., Cesurer L., Yürürdurmaz C., Demirbağ V., Çiçek A., Başgül A. ve Engin A., 1999. Kahramanmaraş koşullarına uygun yüksek verimli arpa çeşitlerinin belirlenmesi. Türkiye 3. Tarla Bitkileri Kongesi (15-18 Kasım) Cilt 1 (Genel ve Tahıllar) s: 234-239, Adana
Kırtok Y. ve Genç İ., 1980. Çukurova koşullarında değişik kökenli arpa çeşitlerinin verim ve verim unsurları üzerine araştırmalar. TUBITAK VII. Bilim Kongesi Yayın No: 552, TOAG Seri No: 115: 157-170

Kün E., 1988. Serin iklim tahılları ders kitabı. A.Ü.Z.F.Yayınları, Yayın No: 1032/299, s:187195, Ankara

Poehlman M.I., 1985. Adaptation and distribution. barley, american society of agronomy Number 26 in the Series, Madison, Wisconsin

Sarı N. ve İmamoğlu A., 2007. Yazlık arpa (Hordeum vulgare L.) çeşitlerinin Ege bölgesinde performanslarının belirlenmesi. Anadolu J. of AARI, 17(1): 1-7 